\title{
HUNTERS AND ANGLERS AT RISK OF LEAD EXPOSURE IN THE UNITED STATES
}

\author{
Richard T. WATSOn AND Dominique AVERY \\ The Peregrine Fund, 5668 West Flying Hawk Lane, Boise, ID 83709, USA \\ E-mail: rwatson@peregrinefund.org
}

\begin{abstract}
Lead $(\mathrm{Pb})$ is toxic and known to have neurological and cognitive development effects at low levels in children, is associated with increased mortality from heart attack and stroke at levels $>2 \mu \mathrm{g} / \mathrm{dL}$ blood lead level in adults, and has other well established and serious health effects in people and wildlife. We used the US Fish and Wildlife Service 2006 National Survey of Fishing, Hunting, and WildlifeAssociated Recreation to assess the numbers and proportions of state populations that may be at risk of lead exposure from lead-based ammunition and fishing gear. In 2006, 12.5 million people (6\% of the population) aged 16 years and older in the United States hunted on 220 million days, of which $45 \%$ were urban residents and 55\% were rural. An estimated 1.6 million children aged 6 to 15 years hunted. Although 28\% of hunters reported using bow and arrows, $93 \%$ used a rifle or shotgun, and $20 \%$ used muzzle-loaders, indicating some hunters used more than one method. Big game hunting, such as deer and elk, was most popular (10.7 million hunters on 164 million days), followed by small game hunting, such as squirrels and rabbits (4.8 million hunters on 52 million days), migratory bird hunting, such as waterfowl and doves (2.3 million hunters on 20 million days), and other animals, such as raccoons and groundhogs (1.1 million hunters on 15 million days). Texas had the largest number of hunters $(979,000)$, followed by Pennsylvania $(933,000)$ and Michigan (721,000). Montana (19\%) had the largest proportion of hunters among the state's population, followed by North Dakota (17\%), and Wisconsin and South Dakota (each 15\%). Lead was made illegal for hunting waterfowl in 1992, but it continues to be the favored metal for bullets and shot used for big game hunting, small game hunting, upland bird hunting (e.g., doves), and varmint (other animals) hunting. In addition to lead exposure from handling ammunition (e.g., hunters who load their own ammunition), lead exposure can occur through inhalation of vapor upon firing, and from ingestion of game meat contaminated with bullet fragments and shot. In 2006, 30 million people (13\% of the population) aged 16 years and older in the United States fished on 517 million days. Freshwater anglers numbered 25.4 million and they fished on 433 million days. Saltwater anglers numbered 7.7 million and they fished on 86 million days. Texas had the largest number of anglers (2.3 million), followed by Florida (1.9 million) and California (1.6 million). Minnesota (28\%) had the largest proportion of anglers among the state's population, followed by Alaska (27\%), and Wyoming (24\%). Lead exposure in anglers can occur in handling and making lead sinkers, and through accidental ingestion. Frequent loss of fishing gear annually contaminates aquatic ecosystems with lead, and causes wildlife mortality and potential sub-lethal effects. Non-lead substitutes for lead ammunition and fishing gear are available and recommended to benefit human and wildlife health. Received 21 May 2008, accepted 28 July 2008.
\end{abstract}

Watson, R.T. AND D. AVERY. 2009. Hunters and anglers at risk of lead exposure in the United States. In R. T. Watson, M. Fuller, M. Pokras, and W. G. Hunt (Eds.). Ingestion of Lead from Spent Ammunition: Implications for Wildlife and Humans. The Peregrine Fund, Boise, Idaho, USA. DOI 10.4080/ilsa.2009.0117

Key words: Angler, exposure, hunter, lead, risk. 
LEAD (РB) IS TOXIC and known to have neurological and cognitive development effects at low levels in children (Canfield et al. 2003), is associated with increased mortality from heart attack and stroke at levels $\geq 2 \mu \mathrm{g} / \mathrm{dL}$ blood lead level in adults (Menke et al. 2006), and has other well established and serious health effects in people and wildlife (Kosnett 2009, Pokras 2009, this volume). Lead shot was banned for hunting waterfowl in the USA in 1991 due to its effects on waterfowl populations and secondary poisoning of avian scavengers, including Bald Eagles (Haliaeetus leucocephalus), but it continues to be the favored metal for bullets and shot used for big game hunting (e.g., deer, elk, moose and caribou), small game hunting (e.g., rabbits), upland bird hunting (e.g., doves), and varmint hunting (e.g., coyote, ground squirrel, and prairie dogs). In addition to lead exposure from handling ammunition (e.g., hunters who load their own ammunition), lead exposure can occur through inhalation of vapor upon firing, and from ingestion of game meat contaminated with bullet fragments and shot (Johansen et al. 2004, 2006, Tsuji et al. 2008). Lead exposure in anglers can occur in handling and making lead sinkers, and through accidental ingestion (St. Clair and Benjamin 2008).

\section{METHODS}

We used the US Fish and Wildlife Service 2006 National Survey of Fishing, Hunting, and WildlifeAssociated Recreation to assess the numbers and proportions of state populations that may be at risk of lead exposure from lead-based ammunition and fishing gear.

\section{RESUlts}

In $2006,12.5$ million people ( $6 \%$ of the population) aged 16 years and older in the United States hunted on 220 million days, of which $45 \%$ were urban residents and 55\% were rural. An estimated 1.6 million children aged 6 to 15 years hunted. Although $28 \%$ of hunters reported using a bow and arrows, $93 \%$ used a rifle or shotgun, and $20 \%$ used muzzle-loaders, indicating some hunters used more than one method. Big game hunting, such as deer and elk, was most popular (10.7 million hunters on 164 million days), followed by small game hunting, such as squirrels and rabbits (4.8 million hunters on 52 million days), migratory bird hunting, such as waterfowl and doves (2.3 million hunters on 20 million days), and other animals, such as raccoons and groundhogs (1.1 million hunters on 15 million days).

Texas had the largest number of hunters $(979,000)$, followed by Pennsylvania $(933,000)$ and Michigan (721,000, Figure 1). Montana (19\%) had the largest proportion of hunters among the state's population, followed by North Dakota (17\%), and Wisconsin and South Dakota (each 15\%, Figure 2).

In 2006, 30 million people (13\% of the population) aged 16 years and older in the United States fished on 517 million days. Freshwater anglers numbered 25.4 million and they fished on 433 million days. Saltwater anglers numbered 7.7 million and they fished on 86 million days. Texas had the largest number of anglers (2.3 million), followed by Florida (1.9 million) and California (1.6 million, Figure $3)$. Minnesota (28\%) had the largest proportion of anglers among the state's population, followed by Alaska (27\%), and Wyoming (24\%, Figure 4).

\section{DISCUSSION}

Hunting is popular throughout the USA, and in some states, such as Alaska where $11 \%$ of the population hunts, much of the state's rural poor subsist on hunting (Verbrugge et al. 2009, Titus et al. 2009, this volume). In at least 14 other states $\geq 11 \%$ of the population hunt, and although annual hunting limits vary by state, those states where it is most popular could reasonably expect significant dietary intake of game meat among some sectors of the population and therefore potentially significant lead exposure from lead-based ammunition. 


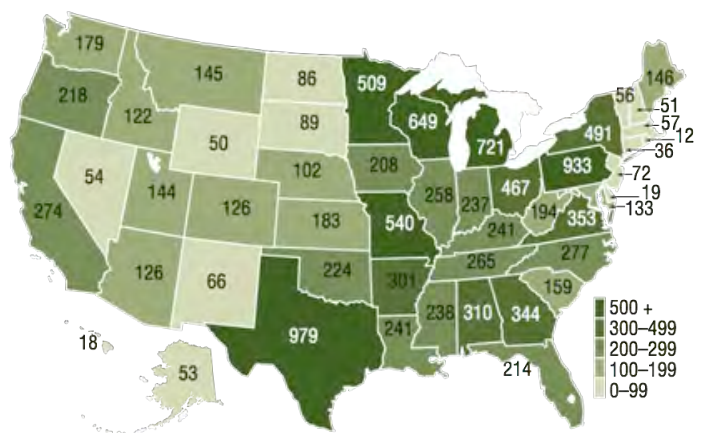

Figure 1. The number (in thousands) of hunters in each state in 2006.

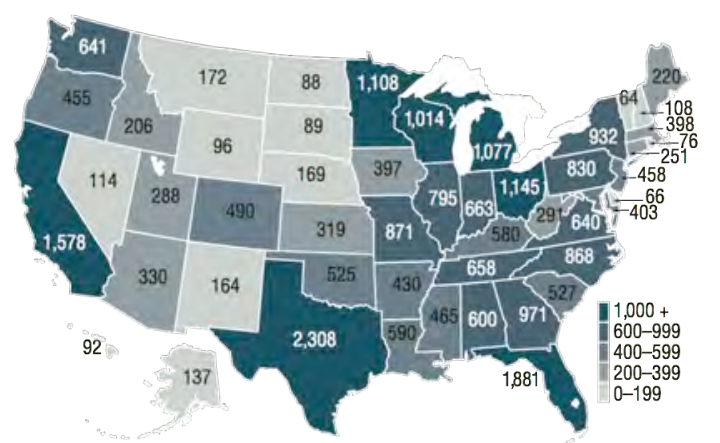

Figure 3. The number (in thousands) of anglers in each state in 2006.

The number of people exposed to lead from ingestion of contaminated game meat is unknown, but likely includes hunters, their families and friends, and the beneficiaries of donated game meat to humanitarian organizations (Avery and Watson 2009, Cornatzer et al. 2009, Hunt et al. 2009, Verbrugge et al. 2009, this volume) and therefore could exceed the number of hunters by several orders of magnitude. The frequency and amount of lead exposure from ingestion of contaminated game meat is unknown, but likely to be greater in people who consume game meat frequently, such as beneficiaries of donated game meat (Avery and Watson 2009, this volume) and others who subsist on this source of protein (Verbrugge et al. 2009, Titus et al. 2009, this volume). An assessment of the health effects of lead exposure from game meat shot with lead-based ammunition should target frequent or long-term consumers using both blood lead concentration to measure short-term exposure (the half-life for lead in blood is about 35 days, Gordon



Figure 2. The proportion (\%) of the population in each state that hunted in 2006.

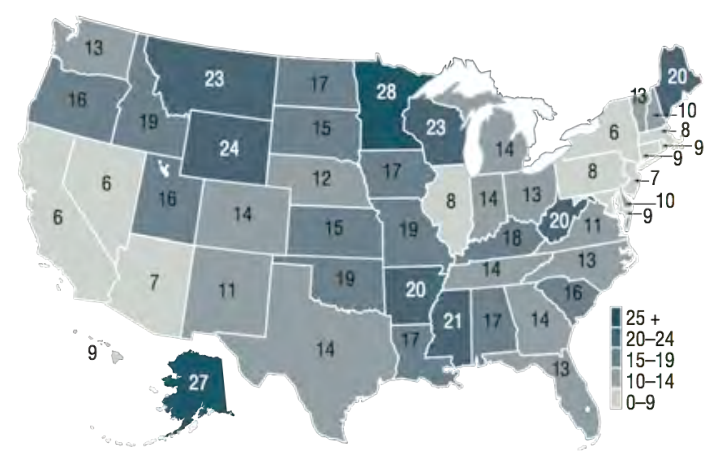

Figure 4. The proportion (\%) of the population in each state that fished in 2006.

et al. 2002) and K-shell X-ray fluorescence of bone to measure long-term exposure ( $\mathrm{Hu}$ et al. 1995). States shown in Figure 2 with a high proportion of the population engaged in hunting, such as Montana, North and South Dakota, Wisconsin, Arkansas, and Maine would be good candidates for further study, as would states with large absolute numbers of hunters, such as Texas, Pennsylvania, Michigan, and Wisconsin (Figure 1).

The large number of hunters (about 12.5 million), who collectively hunt annually on 220 million days, causes concern about the annual mass of lead from unrecovered bullets and shot accumulating in the environment. Unrecovered game and offal is a significant source of lead exposure in scavenging and predatory wildlife resulting in mortality and potential sub-lethal effects (Hunt et al. 2006, Knopper et al. 2006, Pauli and Buskirk 2007, Pokras et al. 2009, Rattner et al. 2009, this volume). Consumption of unrecovered shot is a source 
of lead exposure to game birds that can lead to secondary exposure in predators and humans (Franson et al. 2009, Schulz et al. 2009, Bingham et al. 2009 , this volume).

The number of people exposed to lead from leadbased fishing gear, and the frequency and amount of lead exposure is unknown. Frequent loss of fishing gear annually contaminates aquatic ecosystems with lead, and causes wildlife mortality and potential sub-lethal effects (Friend et al. 2009, Pokras et al. 2009, Rattner et al. 2009, this volume). States in which these effects may be greatest are illustrated in Figure 4 as those with the highest proportion of the population engaged in fishing, such as Alaska, Minnesota, Wisconsin, Wyoming, and Montana.

Large numbers of people are at risk of lead exposure from recreational and subsistence hunting. Although there is special concern for children and women in their child-bearing years, hunters, their families and friends, and beneficiaries of donated game meat may also be at risk. Large amounts of lead are annually deposited in aquatic and terrestrial ecosystems from unrecovered lead bullets, shot and fishing gear, where it can accumulate to appreciable mass over time. Hunters and anglers can avoid the risk of lead exposure by using nonlead ammunition and fishing gear to the benefit of both human and wildlife health.

\section{Literature Cited}

AVERY, D., AND R. T. WATSON. 2009. Distribution of venison to humanitarian organizations in the USA and Canada. In R. T. Watson, M. Fuller, M. Pokras, and W. G. Hunt (Eds.). Ingestion of Lead from Spent Ammunition: Implications for Wildlife and Humans. The Peregrine Fund, Boise, Idaho, USA. DOI 10.4080/ilsa.2009.0114

Bingham, R. J., R. T. LARSEN, J. A. Bissonette, AND J. T. FLINDERS. 2009. Causes and consequences of ingested lead pellets in Chukars. Extended abstract in R. T. Watson, M. Fuller, M. Pokras, and W. G. Hunt (Eds.). Ingestion of Lead from Spent Ammunition: Implications for Wildlife and Humans. The Peregrine Fund, Boise, Idaho, USA. DOI 10.4080/ilsa.2009.0204

Canfield, R. L., J. Henderson, D. A. Cory-
Slechta, C. Cox, T. A. Jusko, And B. P. LANPHEAR. 2003. Intellectual impairment in children with blood lead concentrations below $10 \mu \mathrm{g}$ per deciliter. The New England Journal of Medicine 348:1517-1526.

Cornatzer, W. E., E. F. Fogarty, AND E. W. CORNATZER. 2009. Qualitative and quantitative detection of lead bullet fragments in random venison packages donated to the community action food centers of North Dakota, 2007. Extended abstract in R. T. Watson, M. Fuller, M. Pokras, and W. G. Hunt (Eds.). Ingestion of Lead from Spent Ammunition: Implications for Wildlife and Humans. The Peregrine Fund, Boise, Idaho, USA. DOI 10.4080/ilsa.2009. 0111

Franson, J. C., S. P. Hansen, AND J. H. Schulz. 2009. Ingested shot and tissue lead concentrations in Mourning Doves. In R. T. Watson, M. Fuller, M. Pokras, and W. G. Hunt (Eds.). Ingestion of Lead from Spent Ammunition: Implications for Wildlife and Humans. The Peregrine Fund, Boise, Idaho, USA. DOI 10.4080/ilsa.2009.0202

Friend, M., J. C. Franson, AND W. L. ANDERSON. 2009. Biological and societal dimensions of lead poisoning in birds in the USA. In R. T. Watson, M. Fuller, M. Pokras, and W. G. Hunt (Eds.). Ingestion of Lead from Spent Ammunition: Implications for Wildlife and Humans. The Peregrine Fund, Boise, Idaho, USA. DOI 10.4080/ilsa.2009.0104

Gordon, J. N., A. TAYlor, AND P. N. BennetT. 2002. Lead poisoning: case studies. British Journal of Clinical Pharmacology 53:451-458.

Hu, H., A. ARo, AND A. RotNitzKy. 1995. Bone lead measured by $\mathrm{x}$-ray fluorescence: epidemiologic methods. Environmental Health Perspectives 103, Supp. 1:105-110.

Hunt, W. G., W. Burnham, C. N. Parish, K. Burnham, B. Mutch, AND J. L. OAKS. 2006. Bullet fragments in deer remains: implications for lead exposure in scavengers. Wildlife Society Bulletin 34:168-171.

Hunt, W. G., R. T. WATSON, J. L. OAKS, C. N. PARISH, K. K. BURNHAM, R. L. TUCKER, J. R. BELTHOFF, AND G. HART. 2009. Lead bullet fragments in venison from rifle-killed deer: Potential for human dietary exposure. In R. T. 
Watson, M. Fuller, M. Pokras, and W. G. Hunt (Eds.). Ingestion of Lead from Spent Ammunition: Implications for Wildlife and Humans. The Peregrine Fund, Boise, Idaho, USA. DOI 10.4080/ilsa.2009.0112

Johansen, P., G. ASMUnd, AND F. Riget. 2004. Environmental Pollution 127:125-129.

Johansen, P., H. S. Pederson, G. Asmund, AND F. RigET. 2006. Lead shot from hunting as a source of lead in human blood. Environmental Pollution 142:93-97.

KnopPer, L. D., P. Mineau, A. M. ScheuhamMER, D. E. BOND, AND D. T. MCKINNON. 2006. Carcasses of shot Richardson's Ground Squirrels may pose lead hazards to scavenging hawks. Journal of Wildlife Management 70(1): 295-299.

KosnetT, M. J. 2009. Health effects of low dose lead exposure in adults and children, and preventable risk posed by the consumption of game meat harvested with lead ammunition. In R. T. Watson, M. Fuller, M. Pokras, and W. G. Hunt (Eds.). Ingestion of Lead from Spent Ammunition: Implications for Wildlife and Humans. The Peregrine Fund, Boise, Idaho, USA. DOI 10.4080/ilsa.2009.0103

Menke, A., P. Muntner, V. Batuman, E. K. SilBERGELD, AND E. GUALLAR. 2006 Blood lead below $0.48 \mu \mathrm{mol} / \mathrm{L}(\mu \mathrm{g} / \mathrm{dL})$ and mortality among US adults. Circulation: 114:1388-1394.

PAULI, J. N., AND S. W. BUSKIRK. 2007. Recreational shooting of Prairie Dogs: A portal for lead entering wildlife food chains. Journal of Wildlife Management 71(1):103-108.

POKRAS, M. A., AND M. R. KNEEland. Understanding lead uptake and effects across species lines: A conservation medicine based approach. In R. T. Watson, M. Fuller, M. Pokras, and W. G. Hunt (Eds.). Ingestion of Lead from Spent Ammunition: Implications for Wildlife and Humans. The Peregrine Fund, Boise, Idaho, USA. DOI 10.4080/ilsa.2009.0101

Rattner, B. A., J. C. Franson, S. R. ShefField, C. I. GODDARD, N. J. LEONARD, D. STANG, AND P. J. Wingate. 2009. Technical review of the sources and implications of lead ammunition and fishing tackle on natural resources. Extended abstract in R. T. Watson, M. Fuller, M.
Pokras, and W. G. Hunt (Eds.). Ingestion of Lead from Spent Ammunition: Implications for Wildlife and Humans. The Peregrine Fund, Boise, Idaho, USA. DOI 10.4080/ilsa.2009.0106

Schulz, J. H., X. GaO, J. J. Millspaugh, AND A. J. BERMUdEZ. 2009. Acute lead toxicosis and experimental lead pellet ingestion in Mourning Doves. Extended abstract in R. T. Watson, M. Fuller, M. Pokras, and W. G. Hunt (Eds.). Ingestion of Lead from Spent Ammunition: Implications for Wildlife and Humans. The Peregrine Fund, Boise, Idaho, USA. DOI 10.4080/ilsa.2009.0203

St. Clair, W. S., AND J. Benjamin. 2008. Lead intoxication from ingestion of fishing sinkers: a case study and review of the literature. Clinical Pediatrics 47(1):66-70.

Titus, K., T. L. Haynes, And T. F. Paragi. 2009. The importance of Moose, Caribou, deer and small game in the diets of Alaskans. In R. T. Watson, M. Fuller, M. Pokras, and W. G. Hunt (Eds.). Ingestion of Lead from Spent Ammunition: Implications for Wildlife and Humans. The Peregrine Fund, Boise, Idaho, USA. DOI 10.4080/ilsa.2009.0312

Tsuji, L. J. S., B. C. WAinman, I. D. Martin, C. SUTHERLAND, J-P WEBER, P. DUMAS, AND E. NIEBOER. 2008. The identification of lead ammunition as a source of lead exposure in First Nations: the use of lead isotope ratios. Science of the Total Environment 393:291-298.

US DEPARTMENT OF THE INTERIOR, FISH AND Wildlife SERVICE, AND US DEPARTMENT OF Commerce, US CENSUS Bureau. 2006 National Survey of Fishing, Hunting, and WildlifeAssociated Recreation. [Online.] Available at: http://wsfrprograms.fws.gov/Subpages/National Survey/nat_survey2006_final.pdf. Accessed 1 May 2008.

Verbrugge, L. A., S. G. Wenzel, J. E. Berner, AND A. C. MATZ. 2009. Human exposure to lead from ammunition in the circumpolar north. In R. T. Watson, M. Fuller, M. Pokras, and W. G. Hunt (Eds.). Ingestion of Lead from Spent Ammunition: Implications for Wildlife and Humans. The Peregrine Fund, Boise, Idaho, USA. DOI 10.4080/ilsa.2009.01 